\title{
Immunological and functional characterization of proteins of the Mycobacterium tuberculosis antigen 85 complex using synthetic peptides
}

\author{
S. C. Leão, ${ }^{1 *}$ J. D. Lopes $^{2}$ and M. E. Patarroyo ${ }^{1}$ \\ ${ }^{1}$ Instituto de Inmunologia-Hospital San Juan de Dios, Universidad Nacional de Colombia, Avenida $1^{a}$ 10-01, \\ Bogotá, Colombia \\ ${ }^{2}$ Disciplina de Biologia Celular, Escola Paulista de Medicina, Rua Botucatu, $8628^{\circ}$, 04023-062 São Paulo, Brazil
}

(Received 10 November 1992; revised 16 February 1993; accepted 3 March 1993)

\begin{abstract}
As tuberculosis re-emerges as an important health problem worldwide, new drugs, better diagnostic tests and vaccines are being sought. In order to identify potentially useful peptides for the development of a synthetic vaccine against tuberculosis, immunological and functional studies were performed using proteins of the antigen 85 complex. Western blot (immuno-blot) analysis and a lymphoproliferation study was used to investigate the B- and T-cell immune response of tuberculosis patients, healthy household contacts and normal controls to proteins of the Mycobacterium tuberculosis antigen 85 complex. Peptides derived from the 85A amino acid sequence were synthesized and used in fibronectin-binding and in ELISA assays. A peptide with the sequence CQPACRKAGCQTYKWEC bound to radiolabelled fibronectin in a time-dependent manner and was recognized by human sera in ELISA. This peptide was identified as a potential component of a synthetic vaccine against tuberculosis.
\end{abstract}

\section{Introduction}

The antigen 85 complex is a group of related mycobacterial proteins actively secreted into culture fluids. Three major components have been described by different authors and assigned different names. The P32 antigen described by De Bruyn et al. (1987) and by Borremanns et al. (1989), as well as MPT44 and MPB44 from Nagai's classification of major mycobacterial culture fluid proteins (Nagai et al., 1981) correspond to antigen $85 \mathrm{~A}$ of the classification proposed by Wiker $e t$ al. $(1986 a)$. Both the $\alpha$ antigen cloned and sequenced by Matsuo et al. (1988) and the MPB59 protein, characterized by Wiker $e t$ al. (1986 b), correspond to 85B. Finally, the MPT45 and MPB45 antigens correspond to 85C (Nagai et al., 1991).

In spite of the published data regarding the immunological response of tuberculosis, leprosy and AIDS patients to antigens of the 85 complex (Huygen et al., 1988; Rumschlag et al., 1988; Drabick \& Baker, 1990), the role these antigens play in the development of clinical

\footnotetext{
*Author for correspondence. Tel. 571233 9006; fax 5712803999.

Abbreviations: BCI/NBT, 5-bromo-4-chloro-3-indolyl phosphate/ nitroblue tetrazolium; $\mathrm{FN}$, fibronectin.
}

disease or protective immunity in humans is not yet clearly understood.

Components of antigen 85 complex were shown to be located in the outer cell wall and on the cell surface of Mycobacterium tuberculosis bacilli (Abou-Zeid et al., 1991; Rambukkana et al., 1991) and to participate in the binding of mycobacteria to fibronectin (FN)-coated surfaces (Ratliff et al., 1988). The binding capacity of antigen 85 to FN could have clinical as well as protective significance.

The phagocytosis of mycobacteria by monocytes/ macrophages could be influenced by the interaction between antigen 85 on the surface of mycobacteria, plasma FN, and FN receptors on the surface of the monocyte/macrophage. An immunological response against the 85 complex could interfere in this interaction, affecting the phagocytosis of the bacilli. Although antibodies are not considered to participate in the protective immunity against tuberculosis, it is possible that some degree of protection could be afforded by antibodies that effectively block the interaction between antigen 85 and FN.

The fact that immunization with live mycobacterial vaccine efficiently generates a protective response, while killed preparations do not (Orme, 1988), is further evidence that proteins released by live bacilli are 
important in the development of immunological protection. For the development of new vaccines against tuberculosis, the putative candidate antigens must be extensively studied.

The immunological response of patients, healthy household contacts and normal donors against the proteins of the antigen 85 complex was the main focus of the present work. We have identified a peptide derived from the 85A sequence which shows FN-binding activity and may consequently afford protective immunogenicity.

\section{Methods}

Mycobacterium tuberculosis proteins. $M$. tuberculosis $\mathrm{H} 37 \mathrm{Rv}$ (TMC 102) was obtained from the Trudeau Mycobacterial Collection, Canada. Proteins were obtained by sonication as previously described (Parra et al., 1991). Briefly, mycobacteria were grown in Sauton medium for 4-6 weeks, to confluence, recollected by filtration on a sintered glass filter and washed three times with phosphate-buffered saline (PBS). Sonication was performed in a Branson sonicator at $0{ }^{\circ} \mathrm{C}$ in four $15 \mathrm{~min}$ pulses. The sonic extract was subjected to ultracentrifugation at $150000 \mathrm{~g}$ for $1 \mathrm{~h}$ at $4{ }^{\circ} \mathrm{C}$. The supernatant was collected by puncturing the tube with a needle, avoiding the upper lipid layer. Protein concentration was estimated by the Lowry method.

Culture filtrate was obtained from 14-d cultures by filtration through a $0.22 \mu \mathrm{m}$ filter and concentration in YM 10000 Amicon membranes.

Purified antigen 85B from $M$. tuberculosis (MPT59 protein) was kindly provided by Professor Morten Harboe (Institute of Immunology and Rheumatology, Oslo, Norway).

Subjects. Patients with pulmonary tuberculosis (as diagnosed by positive bacilloscopy and culture), and related household contacts, with no symptoms of tuberculosis, were selected at the Hospital Santa Clara, in Bogotá. Normal controls were students from the Universidad Nacional de Colombia, Bogotá, without known contact with tuberculosis. Blood samples were obtained after consent.

Western blots. Proteins from sonic extracts or the purified 85B protein were separated by SDS-PAGE and transferred onto nitrocellulose filters. Commercial molecular mass markers (Promega) or a composite of albumin, ovalbumin, thrombin and immunoglobulin light chains were used for calibration. The filters were incubated with the sera obtained from patients, contacts and controls, in a 1:100 dilution in TBST (10 mM Tris/ $\mathrm{HCl}$ pH 7.5, $150 \mathrm{~mm}-\mathrm{NaCl}, 0.05 \%$ Tween 20 ) for $2 \mathrm{~h}$ and subsequently with alkaline-phosphatase-conjugated antihuman IgG antibodies (Promega) for $1 \mathrm{~h}$. The reaction was developed with BCI/NBT (Promega).

After transfer from SDS-PAGE, nitrocellulose filters containing sonic extracts or culture filtrate were incubated with a $50 \mu \mathrm{g} \mathrm{ml}^{-1}$ solution of FN in TBST for $2 \mathrm{~h}$ at room temperature, with biotinylated rabbit anti-FN antibodies $(1: 500)$ for $1 \mathrm{~h}$ and with streptavidinphosphatase (Sigma) 1:500 for $30 \mathrm{~min}$, and were then developed with BCI/NBT. Rabbit anti-FN antibodies were kindly provided by $\mathrm{Dr}$ Ricardo Brentani (Ludwig Institute for Cancer Research, Brazil) and biotinylated according to Guesdon et al. (1979).

Anti-85B antibodies. Strips of nitrocellulose containing the purified $85 \mathrm{~B}$ protein were incubated with one of the sera recognizing it in Western blots. Anti-85B antibodies were eluted from the filter with $0.2 \mathrm{M}$-glycine $\mathrm{pH} 3.0$ and neutralized with $1 \mathrm{M}$-Tris/ $\mathrm{HCl} \mathrm{pH} 8.0$, as described by Robinson et al. (1988).

Lymphocyte proliferation assay. Mononuclear cells were isolated from blood by centrifugation with Ficoll-Hypaque $(d=1077)$, and resuspended in RPMI 1640 culture medium (Flow Laboratories) supplemented with $2 \mathrm{mM}-\mathrm{L}$-glutamine, $25 \mathrm{~mm}$-HEPES, $10 \%(\mathrm{v} / \mathrm{v})$ foetal calf serum, $100 \mathrm{IU}$ penicillin $\mathrm{ml}^{-1}$ and $40 \mu \mathrm{g}$ gentamicin $\mathrm{ml}^{-1}$. The cells were distributed in 96-well flat-bottom culture plates (Falcon) at a concentration of $1.5 \times 10^{5}$ per well, in triplicate. The proteins of the $M$. tuberculosis sonic extract were separated by preparative SDSPAGE and transferred to a nitrocellulose filter. The bands of $28 / 29 \mathrm{kDa}$ were identified by Western blotting with a positive serum and a horizontal strip of the filter containing these proteins was cut and used to stimulate lymphocytes. $M$. tuberculosis sonic extract and a strip of nitrocellulose filter without antigen were used as positive and negative controls, respectively. Cells with antigens were incubated for $5 \mathrm{~d}$ at $37^{\circ} \mathrm{C}$ in humidified air containing $5 \%(\mathrm{v} / \mathrm{v}) \mathrm{CO}_{2}$. The cultures were then pulsed with $0.8 \mu \mathrm{Ci}(30 \mathrm{kBq})$ of $\left[\right.$ methyl- $\left.{ }^{3} \mathrm{H}\right]$ thymidine (Amersham) for $16 \mathrm{~h}$. The cells were harvested onto glass fibre filter strips and $\left[\right.$ methyl $\left.-{ }^{3} \mathrm{H}\right]$ thymidine incorporation was measured in a liquid scintillation counter (Beckman L-9000). Stimulation indices were calculated by dividing the mean c.p.m. obtained for each serum in the wells containing antigen by the mean c.p.m. from wells stimulated with nitrocellulose without antigen. Lymphocyte proliferation to antigens or to whole sonic extract was considered positive when the stimulation index was at least three standard deviations above the mean of that obtained for the controls.

Peptide synthesis. Twenty-three peptides derived from the reported sequence for the 85A M. tuberculosis protein (Borremans et al., 1989) were synthesized by the solid-phase peptide synthesis method of Merrifield (1963) and the simultaneous multiple solid-phase peptide synthesis method of Houghten (1985). The amino acid sequences of these peptides are shown in Table 2. Cysteines were added at both ends of each peptide to facilitate polymerization and to give better fixation on plates and filters.

$F N$-binding assay. Human plasma FN was purified from human plasma by affinity chromatography on a gelatin-Sepharose column (Pharmacia) according to Engvall \& Ruoslahti (1977). Protein concentration was determined after dialysis against PBS. The absence of contaminating proteins was verified by SDS-PAGE. FN was radiolabelled with ${ }^{125} \mathrm{I}$ using Iodobeads (Pierce). Five microlitres of a $1 \mathrm{~mm}$ solution of each $85 \mathrm{~A}$ peptide were dot-blotted on nitrocellulose filters, in triplicate, and the filters blocked with $10 \mathrm{mM}-\mathrm{Tris} / \mathrm{HCl}$ pH 7.5, $150 \mathrm{~mm}-\mathrm{NaCl}, 3 \%(\mathrm{v} / \mathrm{v})$ Tween 20 , plus $1 \%(\mathrm{w} / \mathrm{v}) \mathrm{BSA}$ (TBSTB), overnight at $4{ }^{\circ} \mathrm{C}$. Filters were then incubated with $50 \mu \mathrm{g}$ radiolabelled FN (specific activity $0.78 \mu \mathrm{Ci} \mu \mathrm{g}^{-1} ; 29 \mathrm{kBq} \mu \mathrm{g}^{-1}$ ) for 15 , $30,60 \mathrm{~min}$ or overnight. Excess FN was washed out with TBST, the dots cut from the filters and the radioactivity measured in a gamma counter. The means of the triplicates were calculated and the counts obtained from a void vial were subtracted.

FAST-ELISA. Sera of 15 patients with pulmonary tuberculosis, 15 household contacts and 15 controls were used in FAST-ELISA as follows. Lids from the Falcon Assay Screening Test System (Becton Dickinson Labware) were coated with $100 \mu \mathrm{l}$ of a $20 \mu \mathrm{g} \mathrm{ml}^{-1}$ solution of peptide in PBS by vigorous agitation for $2.5 \mathrm{~h}$. The lids were washed with PBS plus $0.1 \%$ Tween 20 (PBST), then with demineralized water, and allowed to dry. The lids were incubated for $1 \mathrm{~h}$ with gentle agitation with a 1:20 dilution of each serum in PBST plus $5 \%(w / v)$ skimmed milk, in triplicate, then spray-washed with PBST and incubated for $1 \mathrm{~h}$ with anti-human IgG peroxidase conjugate (TAGO) $1: 1000$ in PBST with $5 \%(\mathrm{w} / \mathrm{v})$ milk. The reaction was developed with TMB peroxidase substrate (Kirkegaard \& Perry Laboratories). The plates were read in an ELISA plate reader at a wavelength of $620 \mathrm{~nm}$. Negative controls for the reactions were performed with lids incubated with an irrelevant peptide (peptide 24 in Table 2) and also by incubating lids with PBST and milk without serum. Positive controls for each peptide were represented by human sera giving absorbances 


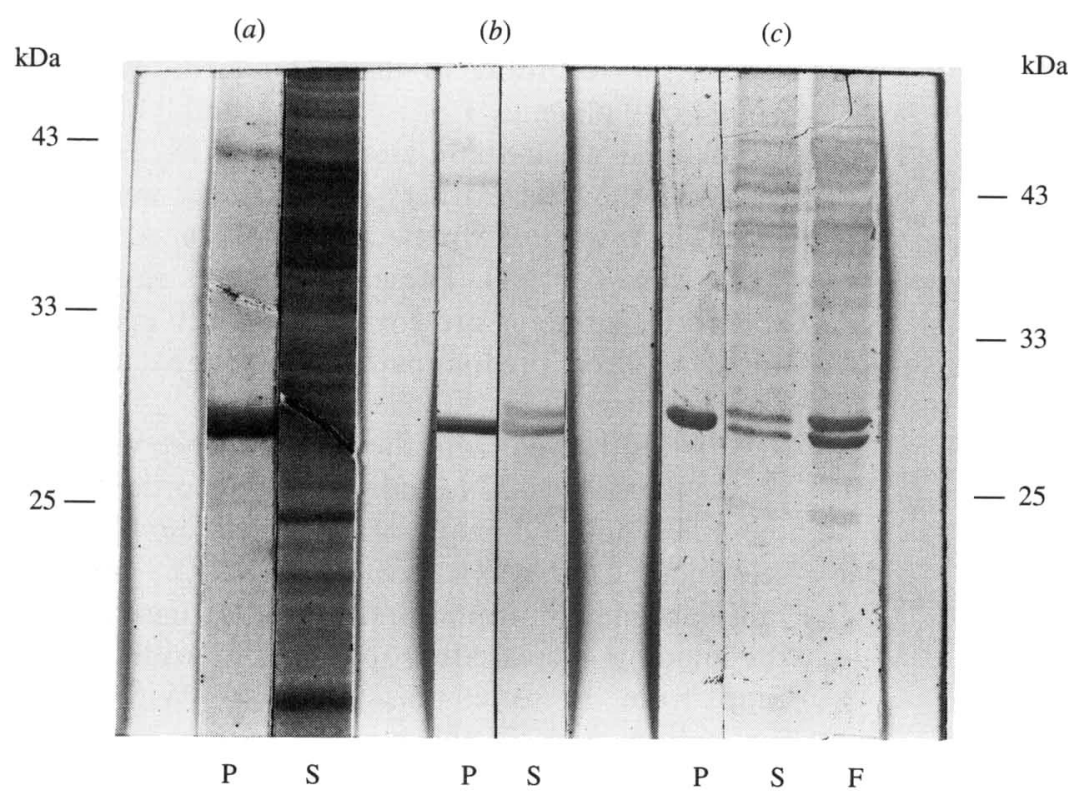

Fig. 1. SDS-PAGE and Western blots with purified 85B antigen (MPT59 protein) (P), sonic extract of $M$. tuberculosis H37Rv (S) and culture filtrate of $M$. tuberculosis H37Rv (F). (a) Coomassie staining; $(b)$ Western blots with eluted anti-85B antibodies; (c) Western blots with fibronectin and biotinylated anti-FN antibodies (Methods).

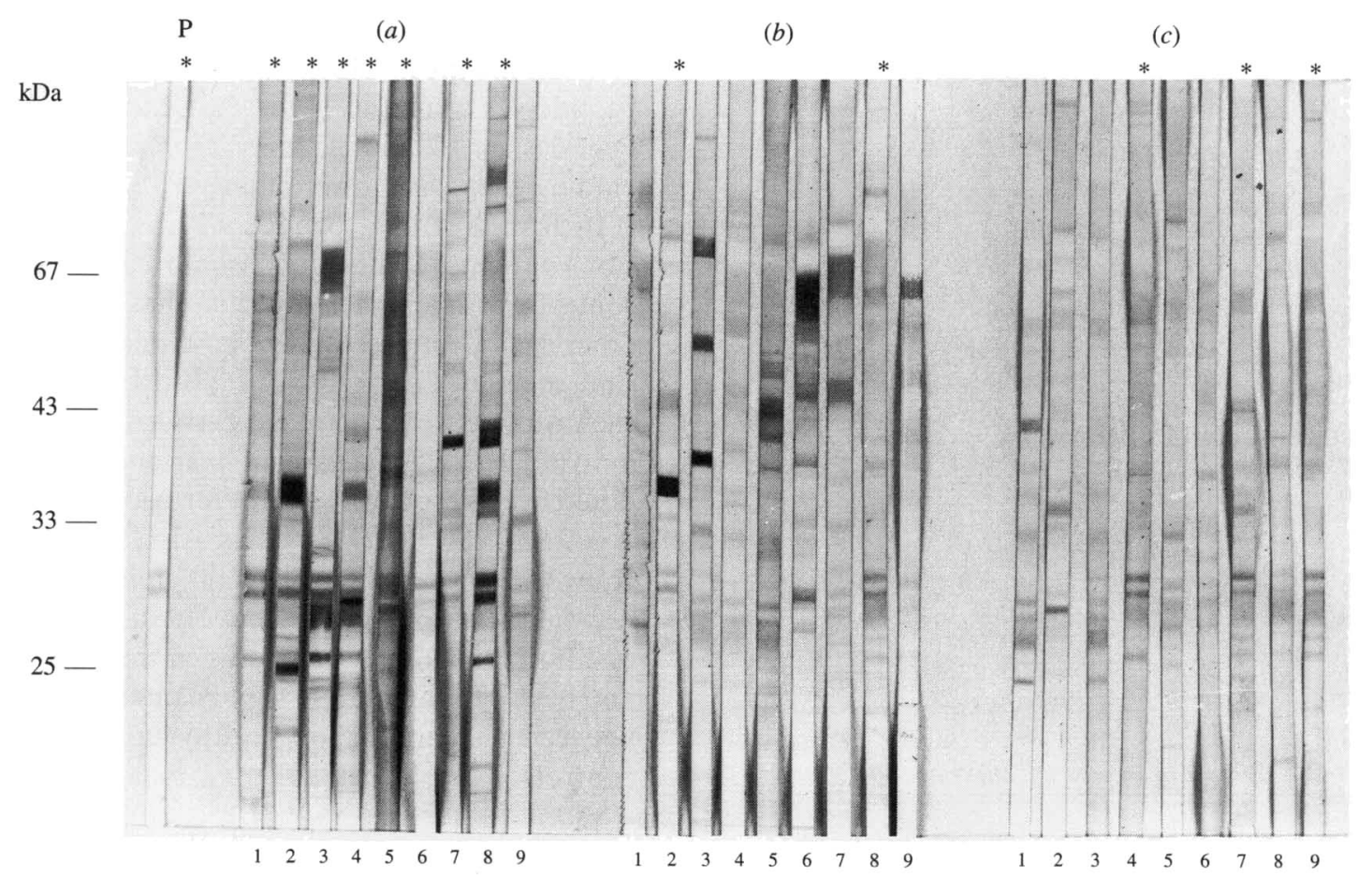

Fig. 2. Western blots against $M$. tuberculosis sonic extract using eluted anti-85B (MPT59) antibodies (P), and sera from nine active tuberculosis patients $(a)$, nine healthy household contact $(b)$, and nine normal controls $(c) .{ }^{*}$ indicates recognition of the $28 / 29 \mathrm{kDa}$ proteins.

greater than three standard deviations above the mean for the controls in a previous experiment. The absorbances obtained for each peptide in each group were compared by analysis of variance and the Tukey Studentized Range Method.

\section{Results}

The components of the 85 family of antigens share a high level of homology and bind to FN (Abou-Zeid et al.,
1991). By using eluted antibodies against antigen $85 \mathrm{~B}$ in Western blots, two bands of 28 and $29 \mathrm{kDa}$ were identified in a sonic extract of $M$. tuberculosis (Fig. 1). Incubation of nitrocellulose strips containing sonic extract proteins with $\mathrm{FN}$ and biotinylated anti-FN antibodies revealed the same $28 / 29 \mathrm{kDa}$ proteins. These results suggest that the proteins of $28 / 29 \mathrm{kDa}$ correspond to components of the 85 family of FN-binding proteins. 
Table 1. Lymphocyte proliferation assay and recognition of 28/29 $\mathrm{kDa}$ proteins by Western blotting in 10 patients (1-10), 9 healthy household contacts (11-19), and 10 normal controls $(20-29)$

The stimulation index (SI) was calculated by dividing the mean of the counts from triplicate wells with antigen by the mean of the counts from wells without antigen. The mean SI for the control group stimulated with $28 / 29 \mathrm{kDa}$ antigens was 0.784 (SD 0.27). With sonic extract the mean SI for controls was 1.552 (SD 0.41). Lymphoproliferation was taken as positive $\left({ }^{*}\right)$ for values 3 standard deviations above the mean SI from controls. ( + ) indicates recognition of $28 / 29 \mathrm{kDa}$ proteins in Western blots; $(-)$ indicates no recognition. Two patients showed lymphoproliferation with both $28 / 29 \mathrm{kDa}$ antigen and sonic extract. Three patients recognized the $28 / 29 \mathrm{kDa}$ antigens by both Western blot and lymphoproliferation. ND, No data.

\begin{tabular}{|c|c|c|c|}
\hline \multirow{2}{*}{$\begin{array}{c}\text { Individual } \\
\text { no. }\end{array}$} & \multicolumn{2}{|c|}{ Stimulation index } & \multirow{2}{*}{$\begin{array}{c}\text { Western } \\
\text { blots } \\
28 / 29 \mathrm{kDa}\end{array}$} \\
\hline & $28 / 29 \mathrm{kDa}$ & Sonicate & \\
\hline 1 & $1 \cdot 16$ & $2 \cdot 00$ & + \\
\hline 2 & 0.50 & 1.20 & + \\
\hline 3 & $5 \cdot 28^{*}$ & $7 \cdot 43^{*}$ & + \\
\hline 4 & 0.75 & $3 \cdot 30^{*}$ & + \\
\hline 5 & ND & ND & + \\
\hline 6 & $2 \cdot 12^{*}$ & 1.50 & - \\
\hline 7 & $2.00^{*}$ & $4 \cdot 86^{*}$ & + \\
\hline 8 & $2 \cdot 16^{*}$ & ND & + \\
\hline 9 & $0 \cdot 30$ & 1.00 & - \\
\hline 10 & 1.50 & 0.30 & ND \\
\hline 11 & $0 \cdot 70$ & $1 \cdot 30$ & - \\
\hline 12 & $0 \cdot 30$ & 0.90 & + \\
\hline 13 & 0.80 & $1 \cdot 30$ & - \\
\hline 14 & 0.60 & $5 \cdot 30^{*}$ & - \\
\hline 15 & $2 \cdot 20^{*}$ & ND & - \\
\hline 16 & $1 \cdot 20$ & ND & - \\
\hline 17 & ND & ND & - \\
\hline 18 & $1 \cdot 10$ & 1.00 & + \\
\hline 19 & $1 \cdot 10$ & $1 \cdot 30$ & - \\
\hline 20 & 0.75 & 1.74 & - \\
\hline 21 & 0.58 & 0.85 & - \\
\hline 22 & ND & $1 \cdot 32$ & - \\
\hline 23 & 0.30 & $1 \cdot 40$ & + \\
\hline 24 & ND & ND & - \\
\hline 25 & 1.00 & 2.00 & - \\
\hline 26 & $1 \cdot 10$ & 2.00 & + \\
\hline 27 & 0.80 & ND & - \\
\hline 28 & 0.60 & ND & + \\
\hline 29 & $1 \cdot 14$ & ND & ND \\
\hline
\end{tabular}

The $28 / 29 \mathrm{kDa}$ proteins were also present in culture filtrate (Fig. 1).

Sera and mononuclear cells from ten patients, nine household contacts and ten controls were used for Western blots and lymphoproliferation assays. Fig. 2 shows that the bands of 28 and $29 \mathrm{kDa}$ from $M$. tuberculosis sonic extract were recognized in Western blots by 7 of 9 patients, 2 of 9 contacts, and 3 of 9 controls. In the lymphoproliferation assay, stimulation indices above 1.59 for the $28 / 29 \mathrm{kDa}$ antigens and above 2.78 for $M$. tuberculosis sonic extract were more than three standard deviations above the mean stimulation index obtained for controls, and were considered positive (Table 1). According to these standards, lymphocytes from 4 of 9 patients, 1 of 8 contacts, and 0 of 8 controls proliferated when stimulated with the $28 / 29 \mathrm{kDa}$ antigen. With the sonic extract, positive results were obtained with cells from 3 of 8 patients, 1 of 6 contacts, and 0 of 8 controls (Table 1). These experiments show that the $28 / 29 \mathrm{kDa}$ proteins present B- and T-cell epitopes, and are recognized predominantly by patients with active disease.

Peptides derived from the 85A sequence were synthesized and used in a FN-binding assay, in order to identify the FN-binding domain of P32. Peptide 13, with the sequence CQPACRKAGCQTYKWEC, bound the radiolabelled $F N$ in the first $15 \mathrm{~min}$ of incubation, and the binding increased proportionally with incubation time, from 15 to $60 \mathrm{~min}$ (Table 2). With overnight incubation, non-specific binding appeared. The experiment was repeated three times with similar results. Peptides 5, 14 and 22 also displayed binding to FN after $15 \mathrm{~min}$ of incubation, increasing proportionally with incubation time. However, the c.p.m. obtained for peptide 13 were the highest at each incubation time. Peptides 5, 14 and 22 may represent secondary FNbinding sites with lower affinity.

In FAST-ELISA, peptide 13 was recognized by sera from patients, healthy household contacts and normal controls, with a higher $A_{620}$ than that obtained for all the other P32 peptides, or for an irrelevant peptide, in a similar assay (Table 3 ). The absorbances obtained for each peptide were compared between the three groups of individuals by analysis of variance. No significant differences were found except for peptide 13 ( $\mathrm{DF}=2.73$, $F=9.82, P=0.0002)$. Using the Tukey Studentized Range Method a significant difference at the $1 \%$ level was found for peptide 13 between the groups of patients and normal controls and between the groups of patients and healthy contacts. No significant difference was found between the groups of healthy contacts and normal controls.

\section{Discussion}

Using two different approaches, with anti-85B antibodies and FN, two bands of 28 and $29 \mathrm{kDa}$ were identified in sonic extracts and culture filtrates of $M$. tuberculosis which correspond to components of the 85 family of $\mathrm{FN}$ binding antigens.

The $85 \mathrm{~A}$ and $\mathrm{B}$ proteins have been identified by others as 30 and $31 \mathrm{kDa}$ proteins present in culture filtrates of different mycobacteria, and have not been detected in sonic extracts (Abou-Zeid et al., 1988). In the present study, the proteins were also identified in the sonic extract; this could be related to differences in the 
Table 2. FN-binding assay with synthetic peptides derived from M. tuberculosis $85 \mathrm{~A}$

(a) Peptides synthesized according to the sequence of $85 \mathrm{~A}$ published by Borremanns et al. (1989). Cysteines at both extremes enhanced fixation to plastic and nitrocellulose through polymerization of peptides. The numbers in parentheses indicate the corresponding positions of the first and the last amino acids from the peptides in the $85 \mathrm{~A}$ preprotein sequence. Peptide 24 is an irrelevant peptide used as control. (b) FN-binding assay. Mean c.p.m. refers to the mean of triplicates for each peptide, minus the blank of the counter, after $15,30,60 \mathrm{~min}$ or overnight $(\mathrm{ON})$ incubation with labelled FN. Peptide 13 showed the greatest FN-binding activity.

\begin{tabular}{|c|c|c|c|c|c|}
\hline \multirow{2}{*}{\multicolumn{2}{|c|}{ (a) Amino acid sequences }} & \multicolumn{4}{|c|}{ (b) Mean c.p.m. } \\
\hline & & \multirow{2}{*}{$\frac{15 \mathrm{~min}}{532}$} & \multirow{2}{*}{$\frac{30 \mathrm{~min}}{1075}$} & \multirow{2}{*}{$\frac{60 \mathrm{~min}}{1332}$} & \multirow{2}{*}{$\begin{array}{c}\text { ON } \\
3175\end{array}$} \\
\hline 1 CMQLVDRVRGAVC & $(1-11)$ & & & & \\
\hline 2 CVRGAVTGMSRRLVVGC & $(7-21)$ & 0 & 760 & 392 & 2155 \\
\hline 3 CAVARLVSGLVGAVC & $(22-34)$ & 890 & 05 & 415 & 2777 \\
\hline 4 CLVVGAVARLVSGLVGC & $(19-32)$ & 477 & 115 & 1072 & 3195 \\
\hline 5 CATAGAFSRPGLPC & $(38-49)$ & 765 & 1402 & 2667 & 2947 \\
\hline 6 CAFSRPGLPVEYLQC & $(42-54)$ & 0 & 130 & 1002 & 1690 \\
\hline 7 CVEYLQVPSPSMGC & $(50-61)$ & 0 & 640 & 402 & 2052 \\
\hline 8 CIKVQFQSGGANSC & $(64-75)$ & 350 & 452 & 1420 & 1582 \\
\hline 9 CALYLLDGLRAQDC & $(77-88)$ & 130 & 580 & 745 & 2375 \\
\hline 10 CDFSGWDINTPAFEWC & $(89-102)$ & 20 & 302 & 620 & 1910 \\
\hline 11 CAFEWYDQSGLSVVMC & $(99-112)$ & 0 & 725 & 1057 & 2157 \\
\hline 12 CPVGGQSSFYSDWYC & $(113-125)$ & 107 & 270 & 1417 & 2427 \\
\hline 13 CQPACRKAGCQTYKWEC & $(126-140)$ & 1987 & 2542 & 8780 & 5852 \\
\hline 14 CWLQANRHVKPTGSC & $(150-162)$ & 812 & 1025 & 2102 & 3705 \\
\hline 15 CMAASSALTLAIYC & $(169-180)$ & 0 & 467 & 790 & 1735 \\
\hline 16 CYAGAMSSGLLDPSQC & $(187-199)$ & 10 & 782 & 505 & 2320 \\
\hline 17 CMSGLLDPSQAMC & $(191-201)$ & 407 & 470 & 1122 & 2320 \\
\hline 18 CTLIGLAMGDAGGYC & $(204-216)$ & 255 & 447 & 502 & 2862 \\
\hline 19 CKASDMWGPKEDPAWQC & $(217-231)$ & 0 & 2147 & 605 & 2617 \\
\hline 20 CKLIANNTRVWVYC & $(241-253)$ & 465 & 1162 & 1855 & 3882 \\
\hline 21 CNLPAKFLEGFVRTSNC & $(265-279)$ & 625 & 0 & 955 & 2960 \\
\hline 22 CYNAGGRHNGVFDFC & $(286-298)$ & 670 & 1780 & 1450 & 3247 \\
\hline 23 CTHSWEYWGAQLNAMC & $(303-316)$ & 177 & 537 & 1182 & 2597 \\
\hline 24 CGPLRDKILVQRNEARPGC & & 0 & 535 & 1205 & 1835 \\
\hline
\end{tabular}

\section{Table 3. FAST-ELISA with peptides from Table 2}

The mean $A_{620}$ was calculated from 25 patients, 25 healthy contacts and 25 controls. Standard deviations are shown in parentheses. The irrelevant peptide is peptide 24 in Table 2 . A significant difference in the recognition of peptide 13 was observed between the three groups by analysis of variance (DF $=2 \cdot 73, F=$ $9.82, P=0.0002)$ and between the group of patients and the two other groups using the Tukey Studentized Range Test at the 1\% level.

\begin{tabular}{lccc}
\hline \hline & \multicolumn{3}{c}{ Mean $A_{620}(\mathrm{SD})$} \\
\cline { 2 - 4 } & \multicolumn{3}{c}{ Other } \\
& Peptide 13 & P32 peptides & $\begin{array}{c}\text { Irrelevant } \\
\text { peptide }\end{array}$ \\
\hline Patients & $0.205(0.09)$ & $0.064(0.063)$ & $0.034(0.031)$ \\
Contacts & $0.143(0.05)$ & $0.048(0.043)$ & $0.034(0.036)$ \\
Controls & $0.126(0.04)$ & $0.042(0.041)$ & $0.019(0.011)$ \\
\hline \hline
\end{tabular}

protocols used for its production. Abou-Zeid et al. (1988) postulated that these proteins must be present on the surface of the bacilli, as well as being secreted.
Recently, using monoclonal antibodies and sub-cellular fractions, Rambukkana et al. (1991) confirmed the presence of proteins of the antigen 85 complex in the cell wall and on the cell surface of mycobacteria. These results agree with the detection of the 85 complex proteins by Western blots in sonic extracts.

Pessolani \& Brennan (1992) found no evidence of the FN-binding capacity of Mycobacterium leprae and BCG 85 complexes. They used FN, followed by anti-FN monoclonal antibody and alkaline-phosphataseconjugated secondary antibody in Western blots and dot blots. In the present study, no FN-binding activity was detected when a similar protocol was used: FN, followed by rabbit anti-FN antibodies and by alkalinephosphatase-conjugated goat anti-rabbit immunoglobulin G (Promega) (data not shown). It is possible that the structure with a secondary antibody became so large that it detached during the subsequent washing. The results shown in Fig. 1 were obtained with biotinylated anti-FN antibodies, bypassing the use of a secondary antibody. The results presented here confirm 
the previously observed FN-binding properties of proteins of the 85 complex.

The different molecular masses of our identified proteins could be related to the electrophoresis system used. Using two different standards, as described in Methods, the calculated molecular mass always corresponded to 28 and $29 \mathrm{kDa}$. Sera recognizing these two bands also recognized the purified $85 \mathrm{~B}$ protein, with the same estimated molecular weight as the $28 \mathrm{kDa}$ band (data not shown), suggesting that the lower band corresponds to MPT59, or $85 \mathrm{~B}$. Moreover, the Nterminal sequence of the $29 \mathrm{kDa}$ band, purified by elution from acrylamide gels, corresponds to the homologous $\mathrm{N}$-terminal sequence of the three 85 proteins (Wiker et al., 1990) (data not shown).

These proteins were recognized mainly by active pulmonary tuberculosis patients. Within this group, Bcell was more important than T-cell recognition. This is in accordance with previous observations showing that acutely ill tuberculosis patients present high titres of antibodies against mycobacterial proteins, and that these antibodies could play a role at the beginning of the infection (Falla et al., 1991, David, 1990).

Patients, healthy contacts and controls recognized the $28 / 29 \mathrm{kDa}$ antigens in Western blots. As these proteins are shared among different strains of mycobacteria, it is possible that this recognition could be related to contact with environmental mycobacteria. Nevertheless, the difference in the recognition by active tuberculosis patients and the other groups is noteworthy, suggesting that the production of anti- 85 antibodies could be related to the bacterial load. Harboe et al. (1990) demonstrated in animals that antibodies to the proteins of the 85 complex could be useful as a general indicator of mycobacterial infection. However, these antibodies would be of limited value for the specific diagnosis of $M$. tuberculosis infections in humans, because of the great cross-reactivity of these antigens between mycobacteria. However, the 85 antigens, or peptides derived from them, could be used as components of diagnostic assays together with other more specific antigens.

Regarding the lymphoproliferation studies, the stimulation indices obtained were low in general, indicating that the incorporation of thymidine did not increase significantly after in vitro stimulation of $T$ cells with the antigens. The mean stimulation index from controls stimulated with $28 / 29 \mathrm{kDa}$ antigens was less than 1 , suggesting that these antigens might have an inhibitory effect upon the cells. There were more individuals from the patient group showing positive stimulation by $28 / 29 \mathrm{kDa}$ antigens than individuals from contact or control groups, and similar results were observed with total sonic extracts.

These results indicate that the 85 complex proteins secreted by mycobacteria are immunogenic, this being a necessary condition for their use in the development of diagnostic tests and vaccines against tuberculosis. Although the cross-reactivity of these proteins between different species of mycobacteria would be a problem for diagnostic testing, this characteristic would be advantageous for the inclusion of the 85 complex proteins, or peptides derived from them, in a new generation of vaccines.

Using peptides derived from the sequence of $85 \mathrm{~A}$ we identified one peptide - 13 -involved in the FN-binding property of $85 \mathrm{~A}$. A sequence almost identical of that of peptide 13 is present in $85 \mathrm{~B}$, with two amino acid substitutions: $\mathrm{Q}$ for $\mathrm{S}$ and $\mathrm{R}$ for $\mathrm{G}$ in the first and fifth positions, respectively (Borremans et al., 1989). In 85C, the amino acid sequence of this region is completely different (Content et al., 1991). In fact, it is the largest motif ( 8 residues) in the entire sequence that differs significantly from the sequence of the other two proteins. It is noteworthy that while FN-binding activity has been described for both $85 \mathrm{~A}$ and $85 \mathrm{~B}$, it has not yet been clearly demonstrated for $85 \mathrm{C}$. This result, taken together with the results presented here, suggests that this amino acid sequence is related to the observed activity.

In the ELISA assay with synthetic peptides from 85A a significant difference in the recognition of peptide 13 was observed between the group of patients and the two other groups of healthy household contacts and normal controls. This is consistent with the preferential recognition of the 85 antigens by patients in Western blots and lymphoproliferation studies and suggests that peptide 13 could be a dominant epitope recognized by the individuals studied in these tests. Studies have yet to be done to determine the T-cell immunogenicity of this peptide as well as its protective potential in animal models.

If the interaction of $M$. tuberculosis bacilli with $\mathrm{FN}$ is an important pathogenic mechanism in tuberculosis, then an immunological response blocking this interaction could afford protection. We propose peptide 13, CQPACRKAGCQTYKWEC, as a good candidate component of a subunit synthetic vaccine against tuberculosis, together with other peptides derived from different immunogenic proteins of $M$. tuberculosis.

This work forms part of a thesis submitted by S. C. Leão to the Discipline of Cell Biology of the Escola Paulista de Medicina, in São Paulo, Brazil, in partial fulfilment of the requirement for the doctoral degree.

This work was supported by grant number 203779/89.4 from Conselho Nacional de Desenvolvimento Científico e Tecnológico (CNPq) and by the Presidency of the Republic of Colombia, the Colombian Ministry of Public Health, and the German Leprosy Relief Associatio.

We thank Oscar Orozco (Instituto Nacional de Cancerologia, Bogotá, Colombia), Patricia del Portillo, Carlos A. Parra and Ricardo R. Brentani (Ludwig Institute for Cancer Research, São Paulo Branch, 
Brazil) for helpful discussion, Fanny Guzmán for providing peptides, Tim Burke (Scripps Clinics, La Jolla, USA) and Luz Mary Salazar for performing $\mathrm{N}$-terminal sequences.

\section{References}

Abou-Zeid, C., Ratliff, T. L., Wiker, H. G., Harboe, M., Bennedse, J. \& Rook, G. W. A. (1988). Characterization of fibronectin-binding antigens released by Mycobacterium tuberculosis and Mycobacterium bovis BCG. Infection and Immunity 56, 3046-3051.

Abou-Zeid, C., Garbe, T., Lathigra, R., Wiker, H. G., Harboe, M., RooK, G. W. A. \& Young, D. B. (1991). Genetic and immunological analysis of Mycobacterium tuberculosis fibronectin-binding proteins. Infection and Immunity 59, 2712-2718.

Borremanns, M. L., De Wit, G., Volckaert, G., Ooms, J., De Bruyn, J., HuYgen, K., Van Vooren, J. P., Stelandre, M., VerhofstadT, R. \& Content, J. (1989). Cloning, sequence determination, and expression of a 32-kilodalton protein gene of Mycobacterium tuberculosis. Infection and Immunity 57, 3123-3130.

Content, J., de la Cuvellerie, A., De Witt, L., Vincent-LevyFrébault, V., OOMS, J. \& De BruYN, J. (1991). The genes coding for the antigen 85 complexes of Mycobacterium tuberculosis and Mycobacterium bovis BCG are members of a gene family: cloning and sequence determination, and genomic organization of the gene coding for antigen 85-C of M. tuberculosis. Infection and Immunity 59, 3205-3212.

DAvid, H. L. (1990). The spectrum of tuberculosis and leprosy: what can be the significance of specific humoral response? Research in Microbiology 141, 191-205.

De Bruyn, J., Huygen, K., Bosmans, R., Fauville, M., Lippens, R., Van Vooren, J. P., Falmagne, P., Weckx, M., Wiker, H. G., Harboe, M. \& TURNeER, M. (1987). Purification, partial characterization and identification of a $32 \mathrm{kDa}$ protein antigen of $\mathrm{Myco}$ bacterium bovis BCG. Microbial Pathogenesis 2, 351-360.

DraBiCK, J. J. \& BAKER, J. R., JR (1990). Detection of anti-P32 mycobacterial IgG antibodies in patients with AIDS. Journal of Infectious Diseases 162, 279-280.

EngVall, E. \& Ruoslahti, E. (1977). Binding of soluble form of fibroblast surface protein, fibronectin, to collagen. International Journal of Cancer 20, 1-5.

Falla, J. C., Parra, C. A., Mendoza, M., Franco, L. C., Guzmán, F., Forero, J., Orozco, O. \& Patarroyo, M. E. (1991). Identification of B- and T-cell epitopes within the MTP40 protein of Mycobacterium tuberculosis and their correlation with the disease course. Infection and Immunity 59, 2265-2273.

Guesdon, J. L., Ternynck, T. \& Avrameas, S. (1979). The use of avidin-biotin interaction in immunoenzymatic techniques. Journal of Histochemistry and Cytochemistry 27, 1131-1139.

Harboe, M., Wiker, H. G., Duncan, R., Garcia, M. M., Dukes, T. W., Brookes, B. W., TurcotTe, C. \& NagaI, S. (1990). Protein G-based enzyme-linked immunosorbent assay for anti-MPB70 antibodies in bovine tuberculosis. Journal of Clinical Microbiology 28, 913-921.

HoughtEN, R. A. (1985). General method for the rapid solid phase synthesis of large number of peptides. Specificity of antigen-antibody interaction at the level of individual amino acids. Proceedings of the national Academy of Sciences of the United States of America 82, $5131-5135$.
Huygen, K., Van VoOren, J.-P., Turneer, M., Bosmans, R., Dierckx, P. \& DE BRUYN, J. (1988). Specific lymphoproliferation, gamma interferon production, and serum immunoglobulin $G$ directed against a purified $32 \mathrm{kDa}$ mycobacterial protein antigen (P32) in patients with active tuberculosis. Scandinavian Journal of Immunology 27, 187-194.

Matsuo, K., Yamaguchi, R., Yamazaki, A., Tasaka, H. \& Yamada, T. (1988). Cloning and expression of the Mycobacterium bovis BCG gene for extracellular $\alpha$-antigen. Journal of Bacteriology 170, 3847-3854.

Merrifield, R. B. (1963). Peptide synthesis. I. The synthesis of a tetrapeptide. Journal of the American Chemical Society 85, 2149-2154.

Nagai, S., Matsumoto, J. \& Nagasuga, T. (1981). Specific skinreactive protein from culture filtrate of Mycobacterium bovis BCG. Infection and Immunity 31, 1152-1160.

Nagai, S., Wiker, H. G., Harboe, M. \& Kinomoto, M. (1991). Isolation and partial characterization of major protein antigens in the culture fluid of Mycobacterium tuberculosis. Infection and Immunity 59, 372-382.

ORME, I. M. (1988). Induction of nonspecific acquired resistance and delayed-type hypersensitivity, but not specific acquired resistance, in mice inoculated with killed mycobacterial vaccines. Infection and Immunity 56, 3310-3312.

Parra, C. A., Londoño, L. P., del Portillo, P. \& Patarroyo, M. E. (1991). Isolation, characterization, and molecular cloning of a specific Mycobacterium tuberculosis antigen gene: identification of a species-specific sequence. Infection and Immunity 59, 3411-3417.

Pessolani, M. C. V. \& Brennan, P. J. (1992). Mycobacterium leprae produces extracellular homologs of the antigen 85 complex. Infection and Immunity 60, 4452-4459.

Rambukkana, A., Das, P. K., Chand, A., Baas, J. G., Groothuis, D. G. \& KolK, A. H. J. (1991). Subcellular distribution of monoclonal antibody defined epitopes on immunodominant $M y c o$ bacterium tuberculosis proteins in the 30-kDa region: identification and localization of $29 / 33-\mathrm{kDa}$ doublet proteins on mycobacterial cell wall. Scandinavian Journal of Immunology 33, 763-775.

RatlifF, T. L., McGarr, J. A., Abou-Zeid, C., Rook, G. A. W., StanFord, J. L., AslanZadeh, J. \& Brown, E. J. (1988). Attachment of mycobacteria to fibronectin-coated surfaces. Journal of General Microbiology 134, 1307-1313.

Robinson, P. A., ANDerton, B. H. \& Loviny, T. L. F. (1988). Nitrocellulose-bound antigen repeatedly used for the affinity purification of specific polyclonal antibodies for screening DNA expression libraries. Journal of Immunological Methods 108, 115-122.

RumschlaG, H. S., Shinnick, T. M. \& Cohen, M. L. (1988). Serological responses of patients with lepromatous and tuberculoid leprosy to 30-, 31-, and 32-kilodalton antigens of Mycobacterium tuberculosis. Journal of Clinical Microbiology 26, 2200-2202.

Wiker, H. G., Harboe, M. \& Lea, T. (1986a). Purification and characterization of two protein antigens from the heterogeneous BCG85 complex in Mycobacterium bovis BCG. International Archives of Allergy and Applied Immunology 81, 289-306.

Wiker, H. G., Harboe, M., Nagai, S., Patarroyo, M. E., Ramirez, C. \& CRUZ, N. (1986 b). MPB59, a widely cross-reacting protein of Mycobacterium bovis BCG. International Archives of Allergy and Applied Immunology 81, 307-314.

Wiker, H. G., Sletten, K., Nagai, S. \& Harboe, M. (1990). Evidence for three separate genes encoding the proteins of the mycobacterial antigen 85 complex. Infection and Immunity 58, 272-274. 